\title{
IMPULSIVITAS DAN AGILITAS PADA REMAJA YANG ORANGTUANYA BERCERAI
}

\author{
Sri Hajarwati Ningsi, Asniar Khumas, Kurniati Zainuddin \\ Fakultas Psikologi, Universitas Negeri Makassar \\ Email: srihajarwati.ningsi@gmail.com, asniarkhumas@unm.ac.id \\ kurniatizainuddin@unm.ac.id
}

\begin{abstract}
The inner conflicts resulting from divorce don't cause all adolescents to behave negatively. There are some adolescents who continue to behave positively and are able to learn from the bad experiences of their parents, but there are also adolescents who behave negatively which leads to impulsivity. This qualitative research uses a case study which aims to describe impulsivity and agility in adolescents whose parents are divorced and the factors that influence it. The number of respondents was six adolescent girls whose parent's divorced and six significant others from the respondents. Data were collected using interview techniques. Based on the results of the study, it's known that the forms of impulsivity found include smoking, self-harm, talking abusive to friends, skipping college and always imagining things to self-injury. This is influenced by three factors, such as personality, family and social environment (peers and school). Meanwhile, the forms of agility that were found included respondents busy themselves with organizational and community activities, working at school and not being afraid to build relationships. This is influenced by two factors, such as situational and personality. This research can contribute knowledge in developmental psychology and family psychology.
\end{abstract}

Keywords: Adolescents, Agility, Divorce, Impulsivity

\begin{abstract}
ABSTRAK
Konflik batin yang diakibatkan perceraian tidak membuat semua remaja berperilaku negatif. Ada beberapa remaja tetap berperilaku positif dan mampu belajar dari pengalaman buruk orangtuanya, tetapi ada juga remaja yang berperilaku negatif mengarah pada perilaku impulsivitas. Penelitian kualitatif ini menggunakan studi kasus yang bertujuan untuk mendeskripsikan impulsivitas dan agilitas pada remaja yang orangtuanya bercerai serta faktor-faktor yang mempengaruhinya. Jumlah responden sebanyak enam remaja perempuan yang orangtuanya bercerai dan enam significant others dari responden. Data dikumpulkan menggunakan teknik wawancara. Berdasarkan hasil penelitian diketahui bahwa bentuk impulsivitas yang ditemukan meliputi perilaku merokok, memukuli diri, berbicara kasar pada teman, bolos kuliah, dan selalu membayangkan hal-hal untuk bunuh diri. Hal ini dipengaruhi oleh tiga faktor, yaitu kepribadian, lingkungan keluarga, dan lingkungan sosial (teman sebaya, sekolah). Sedangkan bentuk agilitas yang ditemukan meliputi responden menyibukkan diri pada kegiatan organisasi dan komunitas, sekolah sambil bekerja serta tidak takut untuk menjalin hubungan. Hal ini dipengaruhi oleh dua faktor, yaitu situasional dan kepribadian. Penelitian ini dapat memberi sumbangsih ilmu dalam psikologi perkembangan dan psikologi keluarga.
\end{abstract}

Kata kunci: Agilitas, Impulsivitas, Perceraian, Remaja

\section{PENDAHULUAN}

Keluarga merupakan lingkungan pertama bagi remaja untuk belajar memahami dirinya dan dasar-dasar pola pergaulan. 
Peraturan-peraturan yang ada dalam keluarga mencerminkan harapan tentang hubungan keluarga terhadap pemahaman kebutuhan remaja. Gusnita (2014) mengemukakan bahwa remaja membutuhkan orang dewasa untuk memodifikasi dorongan primitif dan perilakunya, memerlukan pola mengidentifikasi diri dari orangtua untuk membentuk kesadaran fungsi moral, memerlukan bantuan untuk dapat diterima dan dihargai, serta dibutuhkan sebagai anggota keluarga, termasuk orangtua.

Rahmi (2015) mengemukakan bahwa orangtua terdiri dari ayah dan ibu. Idealnya ayah dan ibu harus mengambil peran yang saling melengkapi dalam kehidupan rumah tangga dan perkawinannya, termasuk di dalamnya berperan sebagai model yang lengkap bagi remaja dalam menjalani kehidupannya.

Dagun mengemukakan bahwa adanya kondisi perceraian membuat remaja kehilangan salah satu figur ayah dan ibu.

Ulfiah (2016) mengemukakan bahwa sebelum terjadi perceraian biasanya didahului dengan banyak konflik dan pertengkaran. Konflik dan pertengkaran itu akan membuat anak merasa takut, sedih, dan bingung. Hetherington (Dagun, 2002) melakukan penelitian di California terhadap individu usia empat tahun pada saat kedua orangtuanya bercerai. Penelitian ini ingin mengetahui apakah kasus perceraian itu akan membawa dampak bagi individu usia di bawah empat tahun dan di atas empat tahun. Hasilnya menunjukkan bahwa kasus perceraian membawa trauma pada setiap tingkat usia individu, meski dengan kadar berbeda.

Data yang dikutip detik.com (Saputra, 2019) mengenai kasus perceraian di Indonesia menurut data Mahkamah Agung tahun 2018 sebanyak 419.268. Sementara itu, jumlah kasus perceraian yang terjadi di kota Makassar pada tahun 2019 meningkat dari tahun sebelumnya, yaitu terdapat 3.607 perkara yang telah mendapat putusan (Abdurrahman, 2019). Dan data pengadilan agama Makassar kelas 1A pada bulan januari sampai juni 2020 tercatat ada 1.010 kasus perceraian. Meningkatnya jumlah perceraian di Indonesia khususnya di kota Makassar memiliki dampak yang melibatkan emosi bagi remaja seperti bolos sekolah, tawuran antar remaja, penggunaan narkoba, serta meningkatnya perilaku ngelem dan merokok (Andi, 2020).

Zeratsion, Bjertness, Lien, Haavet, Dalsklev, Halvorsen, Bjertness, dan Claussen (2014) telah melakukan penelitian pada remaja usia 15-19 tahun yang memiliki pengalaman orangtua bercerai di Norwegia. Penelitian ini ingin mengetahui dampak perceraian orangtua terhadap peningkatan perilaku beresiko 
menggunakan metode kuantitatif dengan jumlah responden, yaitu 1.861 untuk studi prospektif dan 2.422 untuk studi crosssectional. Dari penelitian ini diperoleh hasil bahwa tidak ada bukti signifikan antara perilaku beresiko dengan pengalaman perceraian orangtua, namun remaja yang mengalami perceraian orang tua lebih cenderung merokok dan menggunakan doping. Sebagai contoh RR (perempuan, 22 tahun) mengalami perceraian orangtua ketika berusia 16 tahun. RR menuturkan:

"Kalo kebiasaan merokok sebenarnya itu juga hal negatif kak. Karena dulu itu didiagnosis ka punya gejala brokhitis waktu masih kecil. Bahkan hampir ka dulu nda tau beberapa bulan seringka dibawa ke dokter untuk periksa diriku. Ya itumi waktu semester...nda tau semester 5 berhenti ka untuk merokok karena batuk parah. Ku kira karena brokhitis ku kambuh...Nda tau. Nda pernah ka periksa ke dokter spesialis lagi. Dan berhentima. Akhirnya tidak kambuhmi lagi karena sudahka minum obat yang dulu dikasika dokter ku waktu masih kecil. Yang saributamol? Apalah itu. Yang itu ji ku minum. Terus baru pa lagi pake rokok pas semester 89 ini karena hemmm itu juga salah satu pelarianku dari benang kusut yang ada di kepalaku." (RR/Wwcr/02/14102019/Line168-181)

"Karena kanapa di? Kayak ada ki sensasi tersendiri nya di mulut ku...di...tubuh ku . Jadi enakki merokok. Itu ji sih. Apa sih? Kayak ndada ji sesuatu yang menantang sekali ji itu yang pas UKM. Karena lecet $2 \mathrm{ka}$, luka2 ka dan tetap ka ikut. Sakit ka tetap ka ikut."

(RR/Wwcr03/16102019/Line1071-1075)
Berdasarkan hasil wawancara di atas ditemukan bahwa responden merokok sebagai bentuk pelariannya dari masalah perceraian orangtua dan mencari sesuatu yang menantang. Cone, Butler, Balk, dan Koller (2016) mengemukakan bahwa individu berperilaku impulsivitas untuk mengurangi suasana hati yang negatif. Individu yang memiliki impulsivitas tinggi cenderung makan berlebihan, mengeluarkan uang secara berlebihan, minum alkohol dan merokok, berjudi, serta penggunaan narkoba karena individu kurang memiliki kontrol untuk memenuhi keinginannya (McCrae \& Costa, 2003).

Estuti (2013) telah melakukan penelitian pada remaja SMP Negeri 2 Pakuncen Banyumas dengan jumlah responden penelitian, yaitu tiga orang siswa kelas VIII. Penelitian ini menggunakan metode kualitatif untuk mengetahui dampak perceraian orang tua terhadap kematangan emosi remaja yang orangtuanya bercerai. Dari penelitian diperoleh hasil bahwa perceraian merupakan peralihan besar remaja dalam menyesuaikan diri dengan reaksi emosi dan perilaku karena kehilangan salah satu orangtuanya. Selain itu, remaja juga merasakan berbagai macam kepedihan seperti terluka, bingung, marah, dan merasa tidak aman.

Perasaan negatif yang dirasakan remaja akibat dampak perceraian orangtuanya 
seringkali membuat masyarakat dengan mudah memberikan stigma negatif bahwa tindakan kriminal banyak diakibatkan oleh remaja dengan latar belakang orangtua bercerai (Hadianti, Nurwati, \& Darwis (2017). Hal itu membuat masyarakat menggeneralisasikan bahwa remaja dengan latar belakang orangtua bercerai sudah pasti melakukan tindakan yang menyimpang dan dianggap sebagai pelaku kenakalan remaja (Nadeak \& Sadewo, 2014). Namun, stigma negatif yang diberikan masyarakat pada remaja dengan latar belakang orangtua bercerai tidak sepenuhnya benar. Banyak remaja yang orangtuanya bercerai tetapi tetap berprestasi, mampu terlibat dalam kegiatan yang positif, berperilaku baik, dan mampu menyelesaikan tugas-tugas perkembangan meskipun orangtuanya bercerai. Sebagai contoh NA (perempuan, 20 tahun) ketika mengalami perceraian orang tua pada usia 14 tahun. NA menuturkan:

"Kalo saya waktu itu kayak apa dih? Kayak saya jalani ji saja kak. Kalo dibilang kayak pernah ja juga menangis, menangis ja juga. Cuman nda mauka kalo kayak terlalu terbawa arus, saya ikuti terus. Masa mauka sedih terus. Itu saja ku pikirkan toh, kalo misalnya mauka saja buktikanki kalo misalnya tanpa ini ada support atau bantuan apapun dari paceku bisa ja... Itumi kak, kenapa dulu toh waktu yang...iye SMA yang masukka organisasi PMR toh pasti sering sekali ka pulang malam. Karena di basecamp jeka saja. Pokoknya saya sibukkan diriku sesibuk mungkin.
Makanya waktu itu mamaku mengerti sekali kalo misalkan ada kegiatan organisasiku. Karena mungkin bisaji na pahami ka toh, bilang begini anakku karena ada something begitue. Something wrong toh. Jadi nda masalahji. It's oke ji maceku." (NA/Wwcr/02/20022020/Line169-174: 218-225).

Berdasarkan hasil dari wawancara di atas ditemukan bahwa responden merasa sedih ketika perceraian orangtuanya. Namun responden tidak ingin sedih terus serta berusaha menyibukkan diri dengan mengikuti kegiatan organisasi dan komunitas untuk membuktikan kalau dirinya mampu meskipun tanpa ada dukungan dari bapaknya. Bulan (2020) telah melakukan penelitian mengenai resiliensi pada tiga remaja yang memiliki orangtua bercerai. Hasil dari penelitian tersebut diperoleh bahwa responden mampu mengatasi dan bangkit dari keterpurukan yang dirasakan pasca perceraian orangtua. Selain resiliensi, hal itu juga disebabkan oleh agilitas. Lombardo dan Eichinger (2000) mengemukakan bahwa agilitas merupakan kesediaan dan kemampuan untuk belajar dari pengalaman, kemudian menerapkan apa yang telah dipelajari untuk memperoleh kesuksesan di situasi baru. Individu dengan agilitas yang tinggi mengambil pelajaran yang tepat dari pengalaman dan menerapkannya pada situasi baru, cenderung mencari tantangan baru secara terus-menerus, aktif mencari 
feedback dari orang lain dengan tujuan untuk bertumbuh dan berkembang, merefleksi diri, serta mengevaluasi pengalaman dan menarik kesimpulan (De Meuse, Dai, \& Hallenbeck, 2010).

Berdasarkan data yang diperoleh peneliti menemukan bahwa tiga dari enam responden meskipun mengalami konflik batin akibat peristiwa perceraian orangtuanya, namun tidak mengalihkan emosinya pada hal-hal yang negatif serta mampu belajar dari pengalaman orangtuanya dan tetap berperilaku positif. Sebaliknya, data tiga responden yang diperoleh bahwa peristiwa perceraian orangtua membuat responden berperilaku negatif dan mengarah pada perilaku impulsivitas. Adanya permasalahan ini, maka peneliti tertarik untuk meneliti impulsivitas dan agilitas pada remaja yang orangtuanya bercerai serta faktor-faktor yang mempengaruhinya.

\section{METODE}

Penelitian ini menggunakan metode kualitatif berdasarkan studi kasus. Tahap pengumpulan data dimulai dengan penyusunan pedoman wawancara yang didiskusikan bersama pembimbing untuk digunakan dalam proses penelitian. Setelah pedoman wawancara rampung, peneliti kemudian melaksanakan proses wawancara sebanyak tiga kali pada masing-masing responden penelitian, yaitu enam remaja perempuan berusia 12-22 tahun yang memiliki orangtua bercerai dan enam significant others dari responden. Teknik pengumpulan data menggunakan wawancara semi terstruktur menggunakan pedoman wawancara. Setelah data terkumpul, peneliti kemudian melakukan evaluasi tahap awal, yaitu melakukan coding pada setiap hasil wawancara yang telah dilakukan dengan masing-masing responden penelitian. Setelah proses coding dilakukan, peneliti melakukan analisis lebih lanjut kemudian melakukan peer de briefing bersama dengan kedua dosen pembimbing. Tahap selanjutnya, peneliti menggunakan triangulasi data bersama dengan teman dekat responden penelitian, hal ini dilakukan untuk mengetahui kebenaran dari informasi dan data yang diberikan oleh responden. Terakhir, peneliti melakukan triangulasi data dan membuat matriks untuk setiap responden peneltian.

\section{HASIL DAN PEMBAHASAN}

\section{Hasil}

Berdasarkan hasil analisis data yang dilakukan, peneliti menemukan sejumlah kesimpulan. Kesimpulan yang telah teridentifikasi tersebut diuraikan sebagai jawaban pertanyaan penelitian yang akan dijelaskan sebagai berikut:

a. Faktor-Faktor Penyebab Impulsivitas 
1) Urgency

Urgency merupakan suatu kondisi dimana responden mengalami kesulitan dalam mengendalikan dorongan untuk bertindak sebagai respon terhadap emosi negatif. Faktor penyebab terjadinya perilaku impulsivitas pada dimensi pertama, yaitu responden pertama memiliki kesulitan mengontrol emosi negatif dan seringkali menyesali perilaku kasarnya. Hal ini disebabkan karena kebiasaan responden cenderung mengatakan hal-hal kasar pada teman dan juga bapaknya karena responden seringkali mendengar bapaknya berbicara kasar di rumah. Selain itu, kebiasaan merokok responden awalnya karena beradaptasi dari kebiasaan bapak yang kalau ada masalah pelariannya dengan merokok. Responden ketiga dan keempat juga kesulitan mengontrol emosi negatif disebabkan karena kebiasaannya yang cenderung mengikuti emosi. Responden kelima mengaku kesulitan mengontrol kebiasaan bermain sosial media karena tinggal sendiri dan jauh dari orangtua. Responden kedua dan keenam tidak mengalami kesulitan mengontrol emosi negatifnya dan memilih untuk menghindari masalah kalau sedang marah.

\section{2) Premediation}

Premediation merupakan suatu kondisi dimana responden menjadi bijaksana dan penuh pertimbangan. Faktor penyebab terjadinya perilaku impulsivitas pada dimensi kedua,yaitu semua responden selalu memikirkan dampak positif dan negatif sebelum mengambil keputusan. Namun, responden pertama seringkali terlambat dan cenderung memilih melakukan hal negatif karena tidak ada dukungan sosial dari keluarga dan teman. Selain itu, responden pertama juga selektif dalam memilih teman untuk bercerita dan hanya terbuka pada teman yang tinggalnya di luar kota. Responden pertama juga seringkali dihadapkan pada kondisi negatif seperti lingkungan dalam rumah yang tidak nyaman, seringkali diberikan ancaman oleh orangtua ketika bertengkar, dan terbiasa mendapatkan kekerasan fisik dari bapak sejak kecil.

\section{3) Perseverence}

Perseverence merupakan kemampuan individu untuk tetap focus pada tugas yang membosankan atau sulit. Faktor penyebab terjadinya perilaku impulsivitas pada dimensi ketiga, yaitu responden pertama tidak bisa fokus dengan tugasnya karena masalah orangtuanya yang sering kali melempar-lemparkan tanggung jawab. Sedangkan, responden ketiga tidak bisa fokus karena selalu memikirkan masalahnya bukan karena tugasnya yang sulit. Responden keempat dan kelima cenderung menyelesaikan tugas sesuai dengan kemampuannya. Sedangkan, responden 
keenam tetap mengerjakan tugasnya karena merasa memiliki tanggung jawab dan memilih untuk mengerjakan tugas sebelum ditagih karena tidak suka ditekan. Responden kedua, kelima dan keenam memilih untuk tidak menyerah dan selalu menjadikan mama sebagai motivasi.

4) Sensasion Seeking

Sensation seeking merupakan kecenderungan responden untuk menikmati resiko dan terlibat dalam kegiatan berbahaya. Faktor penyebab terjadinya perilaku impulsivitas pada dimensi keempat, yaitu hal-hal yang dilakukan responden ketika memasuki lingkungan baru, yaitu responden pertama ketika masuk ke lingkungan baru cenderung coba-coba. Responden pertama juga bersedia mencoba kegiatan apapun agar tekanan pada dirinya berkurang dan untuk mencari kesenangan. Responden kedua, ketiga, keempat, kelima, dan keenam sebelum masuk ke lingkungan baru responden mencari tahu terlebih dahulu informasi tetang lingkungan yang akan dimasukinya. Responden keenam bersedia mencoba kegiatan apapun untuk bisa belajar hal-hal baru. Sedangkan responden kedua dan kelima tidak bersedia melakukan kegiatan yang menyenangkan dan beresiko karena responden tidak menyukai tantangan. Responden ketiga mengaku melakukan kegiatan yang menyenangkan dan beresiko karena bisa mendapatkan perhatian dari orangtua temannya dan mendapatkan keuntungan berupa materi. Sedangkan, responden keempat dan keenam melakukan hal menyenangkan dan beresiko untuk mendapatkan pengalaman baru.

b. Faktor-Faktor Penyebab Agilitas

1) People Agility

Faktor penyebab terjadinya agilitas pada dimensi pertama, yaitu people agility, responden pertama tidak terlalu terbuka dengan teman karena pernah dikecewakan dan selektif memilih teman bercerita karena belajar dari pengalamannya. Responden kedua merasa sedih dengan perceraian orangtuanya, tapi tidak melampiaskan emosinya pada hal-hal negatif karena dari kecil sudah terbiasa tanpa kehadiran sosok bapak dan juga ada om yang menggantikan sosok bapaknya. Responden ketiga terkadang menyalahkan orangtua namun disesali dan sudah paham dengan kondisi setelah perceraian orangtua. Responden keempat merasa sedih ketika bapaknya bercerai karena takut kalau adiknya mengalami hal yang pernah dialaminya dulu, yaitu dilarang bertemu mamanya dan memilih memendam emosi negatif untuk menjaga perasaan orangtua dengan keluarga barunya. Responden kelima menjadi penengah ketika kakaknya bertengkar karena tidak ingin seperti orangtuanya yang berujung berpisah dan menerima perceraian 
orangtua walaupun kasih sayang dari bapak kurang tapi kasih sayang dari mamanya tidak pernah kurang. Responden keenam mengerjakan tugas karena merasa memiliki tanggung jawab dan tidak suka ditekan.

\section{2) Results Agility}

Faktor penyebab terjadinya agilitas pada dimensi kedua, yaitu results agility, responden kedua memilih untuk tidak menyerah dan selalu menjadikan mama sebagai motivasi. Responden ketiga berinisiatif hidup mandiri dengan bersekolah sambil bekerja untuk membiayai kebutuhan sehari-harinya yang tidak lagi dibiayai oleh orangtuanya. Dan menurut temannya, responden merupakan sosok yang tegar karena mampu menghadapi semua masalahnya dan hidup mandiri. Responden kelima memilih memendam emosi negatif karena tidak ingin membebankan mamanya. Responden keenam menyibukkan diri mengikuti kegiatan organisasi dan komunitas agar bisa lupa dengan perceraian orangtuanya. Selain itu, responden memilih untuk mengerjakan tugas sebelum ditagih karena tidak suka ditekan dan selalu mengingat mama sebagai motivasinya.

\section{3) Mental Agility}

Faktor penyebab terjadinya agilitas pada dimensi ketiga, yaitu mental agility, responden pertama pernah tidak menjalin komunikasi dengan bapaknya karena sempat membencinya, namun kini responden sudah memahami alasannya. Responden kedua sudah memahami perceraian orangtuanya dan tidak takut untuk menjalin hubungan dengan lawan jenis karena responden menganggap bahwa tidak semua laki-laki sama seperti bapaknya. Responden ketiga mampu menerima kondisi mamanya yang sudah menikah lagi dan tidak bertanggung jawab dengan hidupnya. Responden keempat memahami perceraian orangtuanya yang ingin mencari kebahagian dengan menikah lagi. Responden kelima menjaga hubungan bapak dengan keluarga barunya agar tetap harmonis. Responden keenam merasa sedih dengan perceraian orangtuanya tapi tidak ingin terlalu larut dengan kesedihannya dan responden juga ingin membuktikan kalau dirinya bisa meskipun tanpa ada dukungan dari bapaknya. Selain itu, responden memilih cerita dengan beberapa orang, lalu mempertimbangkan solusi yang telah diberikan kepadanya namun tetap mempertimbangkan sesuai kata hatinya.

\section{4) Charge Agility}

Faktor penyebab terjadinya agilitas pada dimensi keempat, yaitu charge agility, responden pertama aktif di organisasi dalam kampus dan cenderung suka coba-coba terlebih dahulu ketika masuk lingkungan baru dan tidak menyukai kegiatan yang monoton. Responden merasa kalau kegiatan 
yang monoton itu tidak membuatnya belajar dan mencoba hal baru untuk bisa menambah wawasannya. Responden kedua aktif di organisasi dakwah dalam kampus dan cenderung mencari informasi terlebih dahulu ketika memasuki lingkungan baru untuk mempersiapkan diri. Responden ketiga tidak aktif organisasi di sekolahnya karena sibuk bekerja, namun responden sering mengikuti lomba untuk mewakili kelasnya. Responden terkadang mencari tahu informasi lingkungan terlebih dahulu dan terkadang juga sering coba-coba. Responden keempat cenderung mencari tahu terlebih dahulu informasi tentang orang-orang yang ada di dalam ketika masuk lingkungan baru, hal-hal yang disukai, dan hal-hal yang sesuai minat responden. Responden kelima cenderung mencari tahu informasi ketika sudah masuk ke lingkungan baru tentang orang-orang dan aturan-aturan dalam lingkungan tersebut. Responden keenam mencoba kegiatan baru untuk bisa belajar hal-hal baru dan tidak ingin melakukan hal yang sia-sia. Responden juga mencari tahu terlebih dahulu informasi tentang lingkungan yang akan dimasukinya untuk lebih mempersiapkan diri.

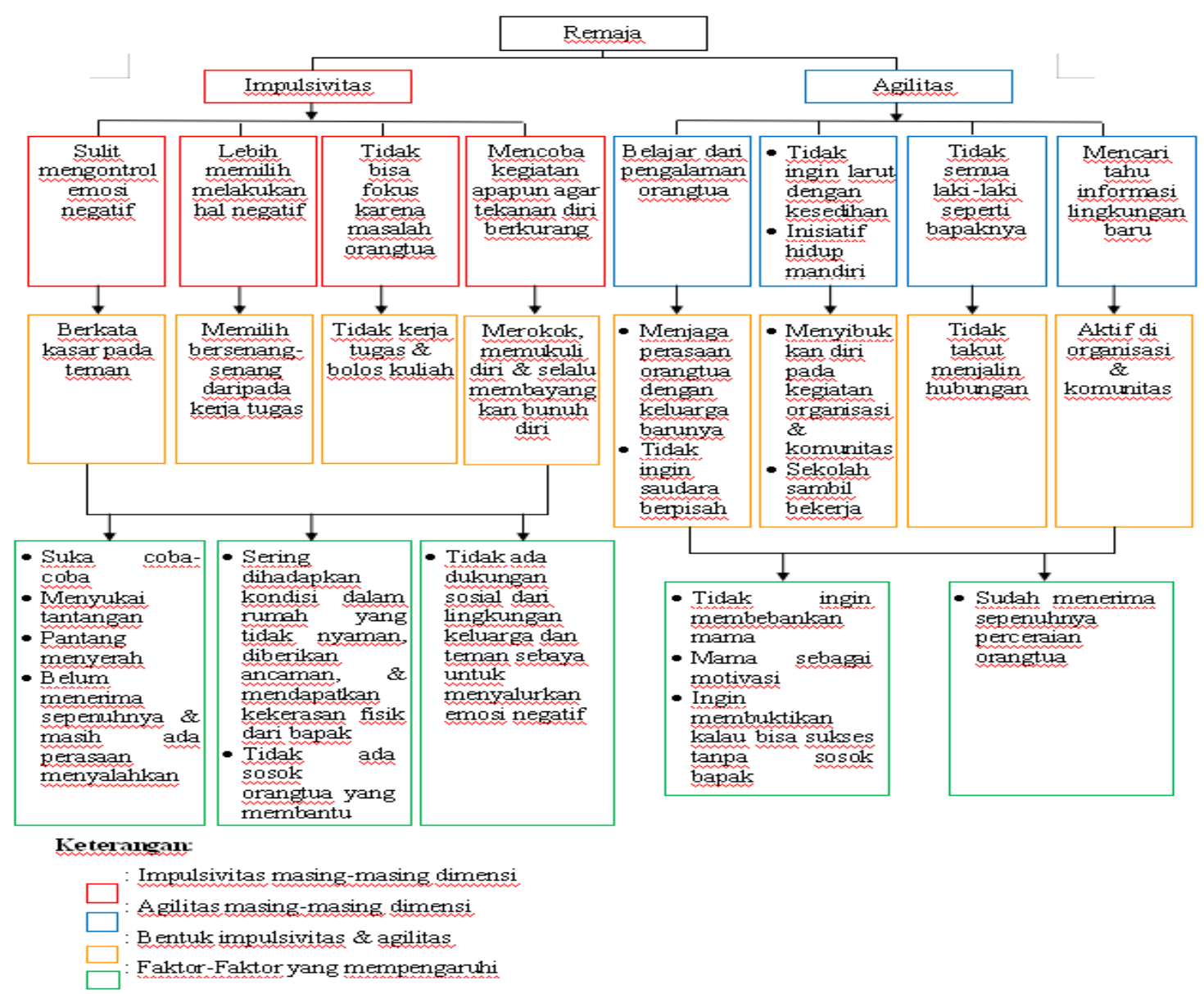


Berdasarkan Gambar 1 diatas, dapat disimpulkan bahwa remaja berperilaku negatif dan mengarah pada perilaku impulsivitas yang secara tidak langsung disebabkan faktor perceraian orangtua seperti berkata kasar pada teman, memilih bersenang-senang daripada kerja tugas, bolos kuliah, merokok, memukuli diri, dan selalu membayangkan bunuh diri. Hal itu disebabkan oleh beberapa faktor, yaitu kepribadian (belum menerima sepenuhnya perceraian orangtua dan masih ada perasaan menyalahkan orangtua, kakek dan nenek), lingkungan keluarga (sering dihadapkan kondisi dalam rumah yang tidak nyaman, diberikan ancaman, dan mendapatkan kekerasan fisik dari bapak, serta tidak ada sosok orangtua yang membantu) dan lingkungan sosial (tidak ada dukungan sosial dari lingkungan keluarga dan teman sebaya untuk menyalurkan emosi negatif).

Remaja berperilaku positif dan mampu mengambil pelajaran dari pengalaman perceraian orangtua seperti menjaga perasaan orangtua dengan keluarga barunya agar tetap harmonis, memberikan pemahaman kepada saudara untuk tidak bertengkar karena tidak ingin saudara berpisah, tidak takut menjalin hubungan dengan lawan jenis karena tidak semua laki-laki seperti bapaknya, tidak ingin larut dengan kesedihan dan menyibukkan diri dengan kegiatan organisasi dan komunitas, serta inisiatif untuk hidup mandiri karena orangtua tidak bertanggung jawab lagi setelah bercerai. Hal ini disebabkan beberapa faktor, yaitu situasional (tidak ingin membebankan mama, mama sebagai motivasi, ingin membuktikan kalau bisa sukses tanpa sosok bapak) dan kepribadian (sudah menerima sepenuhnya perceraian orangtua).

\section{Pembahasan}

Peneliti membuat klarifikasi dari hasil wawancara mengenai faktor impulsivitas dan agilitas pada responden sebagai berikut: a. Impulsivitas

\section{1) Urgency}

Cone, Butler, Balk, dan Koller (2016) mengemukakan bahwa individu berperilaku impulsivitas untuk mengurangi suasana hati yang negatif. Responden pertama juga merokok, memukuli diri, berbicara kasar pada teman, bolos kuliah, dan selalu membayangkan hal-hal untuk bunuh diri. Hal itu dilakukan responden untuk mengalihkan emosi negatifnya ketika dihadapkan pada kondisi yang tidak nyaman oleh orangtuanya. Riley, Combs, Jordan, dan Smith (2015) mengemukakan bahwa urgency negatif memprediksi permulaan perilaku impulsivitas seperti penyalahgunaan zat, minum alkohol, makan berlebihan, dan melukai diri sendiri. Kahar (Lynam, Miller, Miller, Bornovalova, \& Lejuez, 2011) mengemukakan bahwa melukai diri sendiri merupakan akibat 
ketidakmampuan untuk menahan dorongan untuk melukai diri. Whiteside dan Lynam (2001) mengemukakan bahwa tindakan tersebut bertujuan untuk meringankan emosi negatif. Untuk itu, Cyders dan Smith (Neto \& True, 2011) mengemukakan urgency merupakan prediktor kuat untuk masalah dalam kesehatan, pekerjaan, mengkonsumsi alkohol atau narkoba, keluarga, sosial, hukum, dan ketergantungan obat-obatan.

$$
\text { Cyders dan Smith }
$$
mengemukakan tentang kepribadian yang mendasari perilaku impulsivitas pada dua disposisi emosi, yaitu urgency positif dan negatif. Urgency positif mengacu pada kecenderungan untuk terlibat dalam tindakan yang terburu-buru dan keliru ketika mengalami emosi yang sangat positif (Cyders \& Smith, 2008), sedangkan urgency negatif mengacu pada kecenderungan untuk terlibat dalam tindakan yang terburu-buru dan keliru ketika tertekan (Smith \& Cyders, 2016). Oleh karena itu, ketika individu mengalami urgency, individu cenderung akan bertindak terburu-buru atau gegabah (Whiteside \& Lynam, 2001). Dengan kata lain, individu bertindak sesuai dengan kehendak hatinya. Selain itu, ketika mengalami urgency, individu akan melakukan hal-hal yang kemudian disesali untuk membuat dirinya lebih baik.

\section{2) Premediation}

Stoltenberg, Batien, dan Birgenheir (2008) mengemukakan bahwa impulsivitas merupakan kurangnya perencanaan, terlalu cepat merespon, ketidakmampuan untuk menunda kepuasaan dan kontrol emosi negatif serta terlibat dalam perilaku beresiko yang berdampak pada kesehatan dan masalah lainnya seperti penggunaan alkohol dan merokok. Responden pertama selalu memikirkan konsekuensi dari kebiasaannya merokok yang berdampak pada kesehatan responden yang memiliki riwayat penyakit bronkhitis sejak kecil. Selain itu, responden juga selalu memikirkan konsekuensi dari keinginannya untuk bunuh diri. Whiteside dan Lynam (2003) mengemukakan bahwa premediation berkorelasi negatif dengan pertimbangan hati nurani. Faktor ini mengacu pada ketidakmampuan untuk berpikir dan merefleksikan konsekuensi dari tindakan yang diambil.

\section{3) Perseverence}

Responden pertama tidak bisa fokus dengan tugasnya karena masalah orangtuanya yang sering kali melemparlemparkan tanggung jawab. Impulsivitas juga memiliki dampak terhadap sejumlah aspek kehidupan misalnya prestasi akademik. Mosti (Babaeian \& Jamshidzadeh, 2015) mengemukakan bahwa ada korelasi negatif yang signifikan 
antara impulsivitas dengan prestasi akademik, gangguan pikiran, perasaan negatif terhadap diri sendiri, menurunnya kemampuan menikmati dan menyelesaikan suatu kegiatan, meningkatkan perilaku yang bermasalah serta kesulitan berkonsentrasi (Sperry, Lynam, Walsh, Horton \& Kwapil, 2016). Responden ketiga tidak bisa fokus karena selalu memikirkan masalahnya bukan karena tugasnya yang sulit. Dan juga karena tidak ada sosok orangtua yang membantu.

Hal itu seperti yang dilakukan oleh responden keempat dan kelima cenderung menyelesaikan tugas sesuai dengan kemampuannya. Sedangkan, responden keenam mengerjakan tugasnya karena merasa memiliki tanggung jawab dan memilih untuk mengerjakan tugas sebelum ditagih karena tidak suka ditekan. Responden kedua, kelima dan keenam memilih untuk tidak menyerah dan selalu menjadikan mama sebagai motivasi. Dimensi ini mengacu pada kemampuan individu untuk tetap fokus pada suatu tugas yang mungkin membosankan atau sulit (Lepp, 2014). Hal ini menunjukkan bahwa individu dengan perseverance mampu mengabaikan hal-hal yang dapat mengganggu pekerjaannya dan mampu menyelesaikan tugas tepat waktu. Selain itu, individu akan terus berusaha menyelesaikan tugasnya sampai selesai karena ia kurang suka mengabaikan tugas yang didapatnya. Tidak hanya itu saja, individu dengan perseverance tinggi juga akan disiplin dalam mengerjakan tugas, mudah berkonsentrasi, dan produktif (Whiteside \& Lynam, 2001).

4) Sensation Seeking

Santrock (2007) mengemukakan bahwa masa remaja merupakan masa dimana individu sangat tertarik pada seks, obatobatan, musik yang sangat keras, dan pengalaman yang menantang. Hal itu sama seperti dilakukan oleh responden pertama yang bersedia mencoba kegiatan apapun agar tekanan pada dirinya berkurang serta untuk mencari kesenangan dan kegiatan yang menantang. Dan adapun hal-hal yang menyenangkan dan beresiko yang pernah dilakukan responden, yaitu responden pertama hanya ingin tahu bagaimana rasa menyenangkan dari merokok, cenderung memilih hal negatif untuk mencari kesenangan, dan merokok karena mencari sesuatu yang menantang. Doran, Cook, McChargue, dan Spring mengemukakan bahwa individu memiliki keyakinan yang lebih kuat kalau merokok akan memberikan pengalaman menyenangkan dan meringankan bebannya. Riley, Combs, Jordan, dan Smith (2015) mengemukakan bahwa sensation seeking merupakan kecenderungan untuk mencari hal baru yang menantang dan beresiko. Hal ini menunjukkan bahwa individu dengan sensation seeking akan bertindak mencari 
pengalaman baru untuk mendapat kesenangan dan kepuasan, bersedia untuk mencoba apapun demi mendapat kesenangan (Whiteside dan Lynam, 2001).

b. Agilitas

\section{1) People Agility}

People agility merupakan sejauh mana individu mengetahui dirinya dengan baik, belajar dari pengalaman, memperlakukan individu lain secara konstruktif dan resilien dalam tekanan perubahan (DeRue, Ashford, \& Myers 2012).

Responden ketiga terkadang menyalahkan orangtua namun disesali dan sudah paham dengan kondisi setelah perceraian orangtuanya. Responden keempat merasa sedih ketika bapaknya bercerai karena takut kalau adiknya mengalami hal yang pernah dialaminya dulu, yaitu dilarang bertemu mamanya dan memendam emosi negatif untuk menjaga perasaan kedua orangtua dengan keluarga barunya. Agilitas juga sebagai kemampuan untuk mempercepat pemahaman individu tentang situasi dan ide secara fleksibel dalam proses belajar baik dalam sebagian maupun keseluruhan dari pengalaman (DeRue, Ashford, \& Myers 2012).

Responden kelima menjadi penengah ketika kakaknya bertengkar karena tidak ingin seperti orangtuanya yang berujung berpisah dan menerima perceraian orangtua walaupun kasih sayang dari bapak kurang tapi dari mama terpenuhi. Agilitas merupakan kemampuan dan kemauan untuk belajar dengan cepat, dan kemudian menerapkan pengalaman tersebut untuk belajar dengan baik dalam situasi yang baru dan menantang (De Meuse, Dai, \& Hallenbeck, 2008). Responden keenam mengerjakan tugas karena merasa memiliki tanggung jawab dan tidak suka ditekan.

2) Results Agility

Results agility merupakan sejauh mana individu mendapatkan hasil dibawah kondisi yang sulit, menginspirasi individu lain, dan membangun kepercayaan diri terhadap individu lain dengan kehadirannya (DeRue, Ashford, \& Myers 2012). Responden kedua memilih untuk tidak menyerah dan selalu menjadikan mama sebagai motivasi.

Responden ketiga berinisiatif hidup mandiri dengan sekolah sambil bekerja untuk membiayai kebutuhan sehari-harinya yang tidak lagi dibiayai oleh orangtuanya. Dan menurut temannya, responden merupakan sosok yang tegar karena mampu menghadapi semua masalahnya dan hidup mandiri. Individu yang memiliki agilitas akan siap beradaptasi dalam berbagai keadaan sulit dan perubahan yang sangat cepat sehingga bisa mempertahankan kemampuannya untuk tetap menghadapi tantangan (De Meuse, Dai, \& Hallenbeck, 2010).

Responden kelima memilih memendam emosi negatif karena tidak ingin 
membebankan mama. Responden keenam menyibukkan diri mengikuti kegiatan organisasi dan komunitas untuk lupa dengan perceraian orangtua. Selain itu, responden memilih untuk mengerjakan tugas sebelum ditagih karena tidak suka ditekan dan selalu mengingat mama sebagai motivasi. Agilitas merupakan kemampuan untuk mengambil pelajaran yang cepat dan kemudian memberikan gagasan dari sudut pandang berbeda. Kemampuan individu untuk belajar cepat terhadap pengalaman tertentu, fleksibel memindahkan ide dan pengalaman individu lain, serta memaksimalkan potensi pembelajaran nilai dari pengalaman yang diberikan (DeRue, Ashford, \& Myers, 2012).

\section{3) Mental Agility}

Mental agility merupakan sejauh mana individu berpikir tentang masalah dari sudut pandang yang baru dan merasa nyaman dengan ambiguitas, kompleksitas, dan menjelaskan pemikirannya kepada individu lain (DeRue, Ashford, \& Myers 2012). Responden pertama pernah tidak menjalin komunikasi dengan bapaknya karena sempat membencinya, namun sudah memahami alasannya. Responden ketiga mampu menerima kondisi mama yang sudah menikah lagi dan tidak bertanggung jawab dengan hidupnya. Responden keempat memahami perceraian orangtuanya yang ingin mencari kebahagian. Responden kelima menjaga hubungan bapak dengan keluarga barunya agar tetap harmonis.

Responden kedua sudah memahami perceraian orangtua dan tidak takut untuk menjalin hubungan dengan lawan jenis karena tidak semua laki-laki sama seperti bapaknya. Agilitas berfokus pada perilaku individu, pemrosesan kognitif tingkat tinggi, dan pemindahan selektif pengalaman yang dipelajari dalam satu kondisi, serta menerapkannya secara berbeda pada kondisi lain (DeRue, Ashford, \& Myers, 2012).

Responden keenam merasa sedih dengan perceraian orangtuanya tapi tidak ingin terlalu larut dan responden ingin membuktikan kalau dirinya bisa sukses tanpa ada dukungan dari bapaknya. Individu dengan agilitas yang tinggi mengambil pelajaran yang tepat dari pengalamannya dan menerapkan pada situasi-situasi baru, cenderung mencari tantangan baru secara terus-menerus, aktif mencari feedback dari orang lain dengan tujuan untuk bertumbuh dan berkembang, merefleksi diri, serta mengevaluasi pengalaman dan menarik kesimpulan (De Meuse, Dai, \& Hallenbeck, 2010). Selain itu, responden memilih cerita dengan beberapa teman, lalu mempertimbangkan solusi yang telah diberikan dan tetap terakhir mengikuti kata hatinya. 
4) Charge Agility

Charge agility merupakan tingkat keingintahuan individu, memiliki gairah atas ide-ide, dan terlibat dalam aktivitas pengembangan keterampilan (DeRue, Ashford, \& Myers 2012). Semua responden ketika memasuki lingkungan baru cenderung untuk mencari tahu informasi terlebih dahulu untuk mempersiapkan diri, mencari tahu orang-orang yang ada di dalamnya, hal-hal yang disukai dan minat, serta untuk menambah wawasan untuk belajar.

Dalam penelitian ini peneliti mengalami kendala. Pertama, semua responden yang didapatkan peneliti adalah perempuan, peneliti mendapatkan responden laki-laki namun tidak bersedia diwawancarai lebih lanjut. Kedua, terdapat beberapa responden yang kemudian harus dikeluarkan dari penelitian dikarenakan responden tidak dapat diwawancarai lagi.

\section{PENUTUP}

Bersadarkan hasil penelitian dan pembahasan, dapat disimpulkan bahwa bentuk impulsivitas yang ditemukan meliputi perilaku merokok, memukuli diri, berbicara kasar pada teman, bolos kuliah, dan selalu membayangkan hal-hal untuk bunuh diri. Hal ini dipengaruhi oleh tiga faktor, yaitu kepribadian, lingkungan keluarga, dan lingkungan sosial (teman sebaya, sekolah). Sedangkan bentuk agilitas yang ditemukan meliputi responden menyibukkan diri pada kegiatan organisasi dan komunitas, sekolah sambil bekerja serta tidak takut untuk menjalin hubungan. Hal ini dipengaruhi oleh dua faktor, yaitu situasional dan kepribadian.

Adapun beberapa saran yang dapat dipertimbangkan, yaitu:

1. Bagi Remaja Yang Mengalami Perceraian Orangtua

Remaja yang mengalami perceraian orangtua hendaknya dapat memilih lingkungan yang tepat, yang dapat memberikan dukungan padanya. Remaja juga diharapkan mengembangkan kualitaskualitas pribadi yang dapat mendukung dirinya dalam meminimalisir dampak perceraian orangtua.

\section{Bagi Orangtua}

Orangtua sebagai care givers yang paling utama diharapkan mampu menyampaikan pemahaman tentang perceraian dengan baik pada anak. Orangtua juga hendaknya menjaga relasi yang baik dengan mantan suami-istri dalam mengasuh anak serta memastikan bahwa anak tetap merasakan adanya kehadiran dan keterlibatan orangtuanya.

\section{Bagi Keluarga Besar}

Keluarga besar diharapkan dapat berkonstribusi dalam hidup remaja, misalnya dengan memberikan perhatian kasih dan sayang kepada remaja, sehingga hal tersebut dapat menggantikan kasih 
sayang dari figur orangtua.

\section{Bagi Teman Sebaya}

Teman sebaya diharapkan mampu membawa remaja dalam pergaulan yang baik serta dapat memahami kondisi yang alami oleh remaja terkait perceraian orangtuanya.

\section{Bagi Peneliti Selanjutnya}

Penelitian mengenai impulsivitas dan agilitas pada remaja lelaki yang orangtuanya bercerai serta membandingkan setiap dimensi impulsivitas dan agilitas yang terjadi pada remaja perempuan dan laki-laki dengan beberapa faktor yang melatarbelakanginya.

\section{DAFTAR PUSTAKA}

Abdurrahman, M., N. (2019). https://news.detik.com/berita/d4830034/3543-pasutri-di-makassarcerai-selama-2019-mayoritaskarena-ekonomi. Diakses 10 Januari 2020.

Babaeian, K., \& Jamshidzadeh, F. (2015). The relationship between students impulsiveness and timidity with their educational achievement. Biological Forum An International Journal, 7(1), 91-93.

Chen, P., \& Jacobson, K. C. (2013). Impulsivity moderates promotive environmental influences on adolescent delinquency: A comparison across family, school, and neighborhood contexts. Journal Abnormal Child Psychology, 41 (7), 1133-1143. doi:10.1007/s10802013-9754-8.

Costa, P. T., \& McCrae, R. R. (2003). Personality in adulthood: A fivefactor theory perspective. New York: Routledge.
Cone, A. M. B., Butler, R. M., Balk, M. R., \& Koller, K. A. (2016). Dimensions of impulsivity in relation to eating disorder. Journal Eat Disorder, 49 (11), 1027-1031. doi:10.1002/eat.22579.

Creswell, J. W. (2012). Educational research: Planning, conducting, and evaluating quantitative and qualitative research (4th). Boston: Pearson Education, Inc.

Cyders, M. A., \& Smith, G. T. (2008). Emotion-based dispositions to rash action: Positive and negative urgency. Journal Psychology Bullying, 134 (4), 807-828. doi:1037/a0013341.

Cyders, M. A., \& Smith, G. T. (2010). Longitudinal validation of the urgency traits over the first year of college. Journal Personality Assesment, $92 \quad$ (1), 63-69. doi:10.1080/0022389090338125.

Dagun, S. M. (2002). Psikologi keluarga: Peranan ayah dalam keluarga. Jakarta: Rineka Cipta.

De Meuse, K. P., Dai, G., \& Hallenbeck, G. S. (2010). Learning agility: A construct whose time has come. Journal Consulting Psychology, 62 (02), 11-130.

DeRue, D. S., Asford, S. J., \& Myers, C. G. (2012). Learning agility: In search of conceptual clarity and teoretical grounding. Journal Industrial And Organizational Psychology, (2012), 258-279.

Doran, N., Cook, J., McChargue, D., \& Spring, B. (2009). Impulsivity and cigarette craving: Differences across subtypes.

Journal Psychopharmacology, - (207), 365373. doi:10.1007/s00213-009-1661$\mathrm{x}$

Estuti, W. T. (2013). Dampak perceraian orangtua terhadap tingkat kematangan emosi remaja kasus 3 siswa kelas VIII SMP negeri 2 pekuncen Banyumas tahun ajaran 2012/2013. (Skripsi diterbitkan). 
Semarang: Universitas Negeri Semarang.

Gusnita, M. (2014). Hubungan persepsi keterlibatan ayah dalam pengasuhan dan penyesuaian sosial pada remaja lelaki di SMK Pelayaran Putra Samoedra Yogyakarta. (Skripsi diterbitkan). Yogyakarta: Universitas Islam Sunan Kalijaga.

Hadianti, S.W., Nurwati, R.N., \& Darwis, R. S., (2017). Resiliensi remaja berprestasi dengan latar belakang orangtua bercerai. Jurnal Penelitian Dan PKM, 4 (2), 129-389. ISSN: 2442-448x (p), 2581-1126 (e)

Lepp, A., Barkley, J. E., \& Karpinski, A. C. (2014). The relationship between cell phone use, academic, anxiety, and satisfaction with life in college students. Journal Computers In Human Behavior, 31, 343-350. doi:10.1016/j.chb.2013.10.049.

Lombardo, M. M., \& Eichinger, R. W. (2000). High potentials as high learners. Journal Human Resource Management, 39 (4), 321-330.

McCrae, R., \& Costa, P. (2003). Personality in adulthood: A five theory perspective. Experimental Aging Research, 2 (12). doi: $10.1080 / 03610738608259434$.

Moleong, L. J. (2014). Metode penelitian kualitatif. Bandung: PT Remaja Rosdakarya Offset.

Neto, A., \& True, M. (2011). The development and treatment of impulsivity. PSICO, 42(1), 184-193.

Poerwandari, E. K. (2010). Pendekatan kualitatif untuk penelitian perilaku manusia. Kampus UI Depok: LPSP3.

Rahmi. (2015). Tokoh ayah dalam AlQur'an dan keterlibatannya dalam pembinaan remaja. Jurnal Ilmiah Kajian Gender, 5 (2), 203-218.

Santrock, J. W. (2007). Remaja jilid 2 edisi kesebelas. Jakarta: Penerbit Erlangga.
Saputra,

A.

(2019).

https://m.detik.com/news/berita/d4495627/hampir-setengah-jutaorang-bercerai-di-indonesiasepanjang-2018. Diakses 08 Agustus 2019.

Smith, G. T., \& Cyders, M. A. (2016). Integrating affect and impulsivity: The role of positive and negative urgency in substance use risk. Journal Drug Alcohol Depend, 163 (1), doi:10.1016/j.drugalcdep.2015.08.0 38.

Sperry, S. H., Lynam, D. R., Walsh, M. A., Horton, L. E., \& Kwapil, T. R. (2016). Examining the multidimensional structure of impulsivity in daily life. Personality and Individual Differences, 94, 153158. doi:10.1016/j.paid.2016.01.018.

Stoltenberg, S. F., Batien, B. D., \& Birgenheir, D. G. (2008). Does gender moderate associations among impulsivity and health risk behavior?. Journal Addict Behavior, 33 (2), 252-265.

Riley, E. N., Combs, J. L., Jordan, C. E., \& Smith, G. T. (2015). Negative urgency and lack of perseverence: Identification of differential pathways of onset and maintenance risk in the longitudinal prediction of non-suicidal self-injury. Journal Behavior Therapy, 46 (4), 439-448. doi:10.1016/j.beth.2015.03.002.

Ulfiah. (2016). Psikologi keluarga: pemahaman hakikat keluarga dan penanganan problematika rumah tangga. Bogor: Ghalia Indonesia.

Whiteside, S. P. H., \& Lynam, D. R. (2001). The five factor model and impulsivity: Using a structural model of personality to understand impulsivity. Journal Personality And Individual Differences, 30 (-), 669-689. doi: 10.1016/S01918869(00)00064-7. 
Whiteside, S. P., \& Lynam, D. R. (2003). Understanding the role impulsivity and externalizing psychopathology in alcohol abuse: Application of the UPPS impulsive behavior scale. Experimental And Clinical Psychopharmacology, 11(3), 210217. doi:10.1037/1064-
Zeratsion, H., Bjertnes, C. B., Lien, L., Haavet, O. R., Dalsklev, M., Halvorsen, J. A., Bjertness, E., \& Claussen, B. (2014). Does parental divorce increase risk behaviors among 15/16 and 18/19 year-old adolescents? A study from Oslo, Norway. Journal Clinical Practice And Epidemiology in Mental Health, - (10), 59-66. 